\title{
PROSES SENGKETA \\ ANTROPOLOGI HUKUM
}

\author{
OLEH : \\ Nama : Yogi Andri Saputra \\ No BP : 2010003600380 \\ Perguruan Tinggi : Universitas Ekasakti - AAI Padang \\ PRODI STRATA-1 ILMU HUKUM \\ FAKULTAS HUKUM \\ UNIVERSITAS EKASAKTI - AKADEMI AKUNTANSI INDONESIA \\ PADANG
}

\begin{abstract}
Abstrak
Proses sengketa dalam antropologi hukum merupakan suatu hal yang harus memiliki startegi dan cara yang dapat diterapkan dalam menyelsaikan suatu sengketa. Strateginya antara lain opsi hukum (hukum adat, hukum negara, maupun surat perjanjian) dan opsi model resolusi konflik (negosiasim mediasi dan lainya). Strategi mana yang akan diterapkan dalam menyelesaikan proses sengketa antropologi hukum akan menentukan hasil dari proses penyelesaian. Artikel ini mendeskripsikanhukum dan proses penyelesaian sengketa model Antropologi Hukum.
\end{abstract}

Kata Kunci : Sengketa, Antropologi Hukum

\section{PENDAHULUAN}

Model Antropologi Hukum yaitu holistik dengan latar belakang budaya hukum dari masyarakat setempat. Ini memberikan gambaran bahwa hukum tidak hanya dilihat pada persoalan berundangan (normatif) atau hukum adat melainkan ada peran budaya. Peran tersebut dapat dilihat dari cra menyelesaikan masalah dengan budaya yang tertanam. Hukum tidak bisa melihat nilai budaya tersebut tanpa mempelajari Antropologi Hukum sebab pendekatan dari penyelesaian masalah ini memerlukan pemahaman latar belakang budaya setempat.

Sengketa merupakan permasalahan peradilan yang harus diselesaikan. Menurut R Subekti dan $\mathrm{R}$ Tjitrosedibio, peradilan merupakan segala sesuatu yang berkaitan dengan tugas negara untuk ,emegakan hukum dan keadilan. Umumnya seseorang mendapat keadilan melalui pengadilan yang mendapat naungan dari Mahkamah Agung. Ini telah diatur dalam Undang-Undang Republik Indonesia Nomor 2 Tahun 1986 tentang peradilan umum bahwa pengadilan adalah salah satu pelaksana kekuasaan kehakiman bagi rakyat yang mencari keadilan tetapi itu nuga harus mewujudkan kepastian hukum sebagai nilai yang terkandung dalam peraturan hukum..

\footnotetext{
* Materi ini sebagai tugas pengganti UAS Mata Kuliah Antropologi Hukum
} 
Berdasarkan pemahaman diatas, pengadilan masih dipercaya oleh masyarakat untuk menyelesaikan sengketa dan ini diterapkan untuk warga negara mempermudah acces to justice. Permasalahan ini telah diatur oleh Mahkamah Agung dengan mengeluarkan Perma Nomor 1 Tahun 2008 tentang Prosedur Mediasi di Pengadilan. Kenyataanya, mediasi di pengadilan belum efektif.

Realitanya, banyak persoalan sengketa yang tidak terdaftar dalam pengadilan, itupun diatasi dengan budaya hukum. Budaya tersebut diselidiki melalui model antropologi hukum. Menurut Nader dan Todd, model tersebut membagi tiga tahap proses sengketa yaitu tahap pra-konflik, tahap konflik dan tahap sengketa. Budaya hukum juga memiliki prinsip yaitu ide, sikap, kepercayaan, harapan, dan pandangan tentang hukum. Disinilah, Nader dan Todd membagi tujuh cara penyelesaian sengketa yaitu lumping it (membiarkan saja), avoidance (mengelak), coercion (paksaan), negotiation (perundingan), mediation, arbitration, dan adjudication (peradilan) (Siregar, 2012)..

Model antropologi hukum telah diterapkan dalam dua kasus, contohnya diambil dari artikel jurnal BioKultur yang lokasi sengketanya berada di Desa Adat Tengger dan di Kawasan Sungai Brantas Daerah Kabupaten Kediri. Sengketa yang terjadi di Desa Adat Tengger mengenai pemanfaatan hutan konservasi, yang menimbulkan konflik agraria dengan polisi hutan. Secara konflik struktural, antropologi hukum melihat bahwa sengketa tersebut terjadi karena kebijakan pemerintah yang tidak memihak kepada masyarakat. Setelah ditelusuri secara historis, konflik tersebut merupakan warisan dari kebijakan masa lalu yang belum ditangani serius oleh pemerintah produk reformasi. Ini menjadikan rakyat korban konflik/sengketa terus menerus dilanda konflik agraria tanpa adanya penyelesaian, dikarenakan kebijakan pemerintah dan pihak pemilik hutan tidak menempatkan rasa kemanusiaan dan keadilan sosial terhadap masyarakat sekitar (Kinasih, 2016).

\section{PEMBAHASAN}

Pada hakekatnya Proses Sengketa Antropologi Hukum adalah suatu rangkaian proses yang dilakukan untuk mendapatkan penyelesaian suatu sengketa. Proses penyelesaian sengketa terdiri dari dua cara yaitu melalui litigasi (pengadilan) dan non litigasi (luar pengadilan). Dalam proses penyelesaian sengketa melalui litigasi merupakan sarana terakhir (ultimum remidium) bagi para pihak yang bersengketa setelah proses penyelesaian melalui non litigasi tidak membuahkan hasil. Jadi Proses Sengketa Antropologi Hukum adalah rangkaian kegiatan pengumpulan, penataan, pengolahan dan penganalisisan datalfakta (berproses) terhadap suatu sengketa sehingga diperoleh hasil penyelesaian terhadap perkara tersebut.

Model-model penyelesaian sengketa (modes of settlement) yang lajim digunakan adalah (Nader dan Todd, 1978: x) arbitrasi, negosiasi, mediasi, judikasi, paksaan (coercion), dan penghindaran (avoidance).

Sengketa dapat terjadi pada siapa saja dan dimana saja. Sengketa dapat terjadi antara individu dengan individu, antara individu dengan kelompok, antara kelompok dengan kelompok, antara perusahaan dengan perusahaan, antara perusahaan dengan negara, antara negara satu dengan yang lainnya, dan sebagainya. Dengan kata lain, sengketa dapat bersifat publik maupun bersifat keperdataan dan dapat terjadi baik dalam lingkup lokal, nasional maupun internasional.

Sengketa adalah suatu situasi dimana ada pihak yang merasa dirugikan oleh pihak lain, yang kemudian pihak tersebut menyampaikan ketidakpuasan ini kepada pihak kedua. Jika 
situasi menunjukkan perbedaan pendapat, maka terjadi lah apa yang dinamakan dengan sengketa. Dalam konteks hukum khususnya hukum kontrak, yang dimaksud dengan sengketa adalah perselisihan yang terjadi antara para pihak karena adanya pelanggaran terhadap kesepakatan yang telah dituangkan dalam suatu kontrak, baik sebagian maupun keseluruhan. Dengan kata lain telah terjadi wanprestasi oleh pihak-pihak atau salah satu pihak (Nurnaningsih Amriani, 2012: 12).

Menurut Nurnaningsih Amriani (2012: 13), yang dimaksud dengan sengketa adalah perselisihan yang terjadi antara pihak-pihak dalam perjanjian karena adanya wanprestasi yang dilakukan oleh salah satu pihak dalam perjanjian. Hal yang sama juga disampaikan oleh Takdir Rahmadi (2011: 1) yang mengartikan bahwa konflik atau sengketa merupakan situasi dan kondisi di mana orang-orang saling mengalami perselisihan yang bersifat faktual maupun perselisihanperselisihan yang ada pada persepsi mereka saja.

Dengan demikian, yang dimaksud dengan sengketa ialah suatu perselisihan yang terjadi antara dua pihak atau lebih yang saling mempertahankan persepsinya masing-masing, di mana perselisihan tersebut dapat terjadi karena adanya suatu tindakan wanprestasi dari pihak-pihak atau salah satu pihak dalam perjanjian.

Berikut ini beberapa teori tentang sebab-sebab timbulnya sengketa, antara lain :

a. Teori hubungan masyarakat Teori hubungan masyarakat, menitikberatkan adanya ketidakpercayaan dan rivalisasi kelompok dalam masyarakat. Para penganut teori ini memberikan solusi-solusi terhadap konflik-konflik yang timbul dengan cara peningkatan komunikasi dan saling pengertian antara kelompok-kelompok yang mengalami konflik, serta pengembangan toleransi agar masyarakat lebih bisa saling menerima keberagaman dalam masyarakat (Takdir Rahmadi, 2011: 8).

b. Teori negosiasi prinsip Teori negosiasi prinsip menjelaskan bahwa konflik terjadi karena adanya perbedaan-perbedaan diantara para pihak. Para penganjur teori ini berpendapat bahwa agar sebuah konflik dapat diselesaikan, maka pelaku harus mampu memisahkan perasaan pribadinya dengan masalah-masalah dan mampu melakukan negosiasi berdasarkan kepentingan dan bukan pada posisi yang sudah tetap (Takdir Rahmadi, 2011: 8).

c. Teori identitas Teori ini menjelaskan bahwa konflik terjadi karena sekelompok orang merasa identitasnya terancam oleh pihak lain. Penganut teori identitas mengusulkan penyelesaian konflik karena identitas yang terancam dilakukan melalui fasilitasi lokakarya dan dialog antara wakil-wakil kelompok yang mengalami konflik dengan tujuan mengidentifikasikan ancaman-ancaman dan kekhawatiran yang mereka rasakan serta membangun empati dan rekonsiliasi. Tujuan akhirnya adalah pencapaian kesepakatan bersama yang mengakui identitas pokok semua pihak (Takdir Rahmadi, 2011: 9).

d. Teori kesalahpahaman antar budaya Teori kesalahpahaman antar budaya menjelaskan bahwa konflik terjadi karena ketidakcocokan dalam berkomunikasi diantara orangorang dari latar belakang budaya yang berbeda. Untuk itu, diperlukan dialog antara orang-orang yang mengalami konflik guna mengenal dan memahami budaya masyarakat lainnya, mengurangi stereotipe yang mereka miliki terhadap pihak lain (Takdir Rahmadi, 2011: 9).

e. Teori transformasi Teori ini menjelaskan bahwa konflik dapat terjadi karena adanya masalah-masalah ketidaksetaraan dan ketidakadilan serta kesenjangan yang terwujud dalam berbagai aspek kehidupan masyarakat baik sosial, ekonomi maupun politik. Penganut teori ini berpendapat bahwa penyelesaian konflik dapat dilakukan melalui beberapa upaya seperti perubahan struktur dan kerangka kerja yang menyebabkan 
ketidaksetaraan, peningkatan hubungan, dan sikap jangka panjang para pihak yang mengalami konflik, serta pengembangan proses-proses dan sistem untuk mewujudkan pemberdayaan, keadilan, rekonsiliasi dan pengakuan keberadaan masing-masing (Takdir Rahmadi, 2011: 9).

f. Teori kebutuhan atau kepentingan manusia Pada intinya, teori ini mengungkapkan bahwa konflik dapat terjadi karena kebutuhan atau kepentingan manusia tidak dapat terpenuhi/ terhalangi atau merasa dihalangi oleh orang/ pihak lain. Kebutuhan dan kepentingan manusia dapat dibedakan menjadi tiga jenis yaitu substantif, prosedural, dan psikologis. Kepentingan substantif (substantive) berkaitan dengan kebutuhan manusia yang yang berhubungan dengan kebendaan seperti uang, 20 sandang, pangan, papan/rumah, dan kekayaan. Kepentingan prosedural (procedural) berkaitan dengan tata dalam pergaulan masyarakat, sedangkan kepentingan psikologis (psychological) berhubungan dengan non-materiil atau bukan kebendaan seperti penghargaan dan empati (Takdir Rahmadi, 2011: 10).

\section{Proses Sengketa cara Non Litigasi}

Dalam penyelesaian sengketa melalui non-litigasi, kita telah mengenal adanya penyelesaian sengketa alternatif atau Alternative Dispute Resolution (ADR), yang dalam perspektif Undang-Undang Nomor 30 tahun 1999 tentang Arbitrase dan Alternatif Penyelesaian Sengketa, Alternative Dispute Resolution adalah suatu pranata penyelesaian sengketa di luar pengadilan berdasarkan kesepakatan para pihak dengan mengesampingkan penyelesaian sengketa secara litigasi di pengadilan. Akhir-akhir ini pembahasan mengenai alternatif dalam penyelesaian sengketa semakin ramai dibicarakan, bahkan perlu dikembangkan untuk mengatasi kemacetan dan penumpukan perkara di pengadilan maupun di Mahkamah Agung (Buku Tanya Jawab PERMA No.1 Tahun 2008 tentang Prosedur Mediasi di Pengadilan, 2008: 1).

Menurut Pasal 1 angka 10 Undang-Undang Nomor 30 Tahun 1999 tentang Arbitrase dan Alternatif Penyelesaian Sengketa, penyelesaian sengketa melalui non litigasi (luar pengadilan) terdiri dari 5 cara yaitu:

1. Konsultasi: suatu tindakan yang dilakukan antara satu pihak dengan pihak yang lain yang merupakan pihak konsultan. Ini merupakan salah satu metode non litigasi dimana seorang klien (pihak yang bersengketa) mendatangi dan meminta pendapatnya atas masalah yang dihadapi. Saat ini konsultan memberikan pendapatnya sesuai dengan kebutuhan serta keperluan kliennya. Konsultasi ini bersifat personal.

2. Negosiasi: penyelesaian di luar pengadilan dengan tujuan untuk mencapai kesepakatan bersama atas dasar kerja sama yang lebih harmonis. Cara ini tidak memerlukan ahli atau konsultan untuk menengahi sengketa yang dihadapi. Para pihak yang bersengketa bertemu untuk mencapai titik terang penyelesaian masalah. Perundingan ini akan menghasilkan kesepakatan bersama atas dasar yang lebih harmonis dan kreatif.

3. Mediasi: penyelesaian melalui perundingan untuk mencapai kesepakatan di antara para pihak dengan dibantu oleh mediator. Cara penyelesaian sengketa lainnya dalam proses non litigasi. Proses mediasi sendiri hampir sama dengan negosiasi yaitu samasama melakukan perundingan. Bedanya proses mediasi menggunakan bantuan seorang mediator dalam proses perundingan dari pihak-pihak yang terkait.

4. konsiliasi: penyelesaian sengketa dibantu oleh konsiliator yang berfungsi menengahi para pihak untuk mencari solusi dan mencapai kesepakatan di antara para pihak. Sejatinya para pihak yang bersengketa yang menggunakan metode non litigasi melakukan perundingan satu sama lain. Jika menggunakan metode konsiliasi, akan 
ada seorang penengah yang disebut konsiliator. Pihak ini akan mengusahakan penyelesaian dari sengketa yang dihadapi.

5. Penilaian Ahli: pendapat para ahli untuk suatu hal yang bersifat teknis dan sesuai dengan bidang keahliannya. Proses ini merupakan suatu metode non litigasi dimana para pihak bersengketa menanyakan atau meminta pendapat para ahli yang berkompeten sesuai keahliannya.

Akan tetapi dalam perkembangannya, ada juga bentuk penyelesaian di luar pengadilan yang ternyata menjadi salah satu proses dalam penyelesaian yang dilakukan di dalam pengadilan (litigasi). Contohnya mediasi. Dari pasal tersebut kita ketahui bahwa mediasi itu adalah penyelesaian di luar pengadilan, akan tetapi dalam perkembangannya, mediasi ada yang dilakukan di dalam pengadilan.

Di dalam Pasal 1 angka 1 Undang - Undang Nomor 30 Tahun 1999 tentang Arbitrase dan Alternatif Penyelesaian Sengketa menjelaskan bahwa penyelesaian sengketa di luar pengadilan mengenal adanya cara arbitrase yaitu penyelesaian suatu sengketa perdata di luar pengadilan yang di dasarkan pada perjanjian arbitrase yang dibuat secara tertulis oleh para pihak yang bersengketa.

\section{Proses Penyelesaian Sengketa Cara Litigasi}

Proses penyelesaian sengketa yang dilaksanakan melalui pengadilan atau yang sering disebut dengan istilah "litigasi", yaitu suatu penyelesaian sengketa yang dilaksanakan dengan proses beracara di pengadilan di mana kewenangan untuk mengatur dan memutuskannya dilaksanakan oleh hakim.

Litigasi merupakan proses penyelesaian sengketa di pengadilan, di mana semua pihak yang bersengketa saling berhadapan satu sama lain untuk mempertahankan hak-haknya di muka pengadilan. Hasil akhir dari suatu penyelesaian sengketa melalui litigasi adalah putusan yang menyatakan win-lose solution (Nurnaningsih Amriani, 2012: 35).

Prosedur dalam jalur litigasi ini sifatnya lebih formal dan teknis, menghasilkan kesepakatan yang bersifat menang kalah, cenderung menimbulkan masalah baru, lambat dalam penyelesaiannya, membutuhkan biaya yang mahal, tidak responsif dan menimbulkan permusuhan diantara para pihak yang bersengketa. Kondisi ini menyebabkan masyarakat mencari alternatif lain yaitu penyelesaian sengketa di luar proses peradilan formal. Penyelesaian sengketa di luar proses peradilan formal ini lah yang 21 disebut dengan "Alternative Dispute Resolution" atau ADR (Yahya Harahap, 2008: 234).

Litigasi sendiri merupakan suatu istilah dalam hukum mengenai penyelesaian suatu sengketa yang dihadapi melalui jalur pengadilan. Proses tersebut melibatkan pembeberan informasi dan bukti terkait atas sengketa yang dipersidangkan. Gunanya untuk menghindari permasalahan yang tak terduga di kemudian hari. Masalah sengketa tersebut diselesaikan di bawah naungan kehakiman. Dalam UUD 1945 pasal 22 disebutkan bahwa sistem kehakiman di bawah kekuasaan Mahkamah Agung dan badan peradilan di bawahnya.

Badan-badan peradilan tersebut antara lain peradilan umum, peradilan agama, peradilan tata usaha negara, peradilan militer dan mahkamah konstitusi. Penyelesaian sengketa melalui litigasi ada bermacam-macam jenisnya. Jenis kasus litigasi seperti: 
1. Mengenai pembebasan lahan

2. Perbankan

3. Sengketa keperdataan

4. Kejahatan perusahaan (fraud)

5. Penyelesaian atas tuduhan palsu atau perebutan hak asuh anak (difasilitasi oleh pengadilan agama)

Proses penyelesaian sengketa melalui jalur peradilan atau litigasi seringkali disebut dengan ultimum remedium. Jadi maksudnya, litigasi adalah sarana akhir dari penyelesaian sengketa. Hasil akhir dari litigasi mempunyai kekuatan hukum mengikat terhadap pihak-pihak yang terkait di dalam sengketa tersebut.

\section{Perbedaan Litigasi dan Non Litigasi}

Bersengketa dengan pihak lain bukanlah keadaan yang menguntungkan. Banyak yang harus dikorbankan termasuk waktu dan uang. Sebelum beralih ke penyelesaiannya sebenarnya apa itu sengketa?Istilah sengketa di dalam Kamus Besar Bahasa Indonesia (KBBI) merupakan suatu situasi dimana ada suatu hal yang menyebabkan perselisihan. Bisa dalam bentuk perselisihan kecil ataupun perselisihan besar. Pihak yang tidak puas atas perselisihan tersebut bisa melakukan perundingan untuk menemukan penyelesaian.

Penyelesaian yang ditawarkan diatur dalam UU No 30 Tahun 1999 pasal 1 ayat 10. Dalam Undang-Undang mengenai Arbitrase dan Alternatif Penyelesaian Sengketa mengindikasikan bahwa sengketa bisa saja diselesaikan melalui jalur peradilan atau jalur peradilan alternatif (litigasi atau non litigasi). Alternatif ini banyak diberikan terutama pada sengketa yang masuk ke dalam kasus perdata.

Seperti yang diketahui proses litigasi berarti membawa permasalahan sengketa ke jalur hukum sedangkan proses non litigasi penyelesaiannya berdasarkan itikad baik yang dimiliki para pihak yang bersengketa. penyelesaian sengketa di luar jalur pengadilan sesuai kesepakatan bersama dan tertulis dalam sebuah perjanjian inilah yang disebut juga sebagai arbitrase.

\section{PENUTUP}

sengketa ialah suatu perselisihan yang terjadi antara dua pihak atau lebih yang saling mempertahankan persepsinya masing-masing, di mana perselisihan tersebut dapat terjadi karena adanya suatu tindakan wanprestasi dari pihak-pihak atau salah satu pihak dalam perjanjian.

Proses sengketa yang dapat ditempuh oleh orang maupun golongan yang bersengketa dapat dilakukan dengan dua cara, yaitu :

1. L1tigasi

Yang mana suatu proses menyelesaikan suatu sengketa secara hukum atau melalui jalur pengadilan

2. Non Litigasi

Yang mana proses menyelesaikan sengketa nya dilakukan dengan : 
- Konsultasi

- Negosiasi

- Mediasi

- Konsilidasi

- Penilaian Ahli 


\section{DAFTAR PUSTAKA}

https://core.ac.uk/reader/289799250

https://www.google.com/url? sa $=t \& r c t=j \& q=\&$ esrc $=s \&$ source $=w e b \& c d=\& c a d=r j a \& u a c t=$ $8 \& v e d=2 a h U K E$ winile $Q u \_3 u A h W R 4 H M B H e 6 D C u A Q F j A J e g Q I B B A D \& u r l=h t t p s \% 3 A \% 2 F$ $\% 2$ Feprints.uny.ac.id\%2F22029\%2F4\%2F4.BAB\%2520II.pdf\&usg=AOvVaw1 uYFylilfbttEx $7 U X l x Z P O$

https://www.dslalawfirm.com/litigasi/

https://id.wikipedia.org/wiki/Penyelesaian_sengketa

http://www.bahasahukum.net/2018/10/16/penyelesaian-sengketa-dengan-modelantropologi-hukum 